\title{
The intergenerational effects of war on the health of children
}

\author{
Delan Devakumar ${ }^{1 *}$, Marion Birch², David Osrin¹, Egbert Sondorp ${ }^{3}$ and Jonathan CK Wells ${ }^{4}$
}

\begin{abstract}
Background: The short- and medium-term effects of conflict on population health are reasonably well documented. Less considered are its consequences across generations and potential harms to the health of children yet to be born.

Discussion: Looking first at the nature and effects of exposures during conflict, and then at the potential routes through which harm may propagate within families, we consider the intergenerational effects of four features of conflict: violence, challenges to mental health, infection and malnutrition. Conflict-driven harms are transmitted through a complex permissive environment that includes biological, cultural and economic factors, and feedback loops between sources of harm and weaknesses in individual and societal resilience to them. We discuss the multiplicative effects of ongoing conflict when hostilities are prolonged.

Summary: We summarize many instances in which the effects of war can propagate across generations. We hope that the evidence laid out in the article will stimulate research and - more importantly - contribute to the discussion of the costs of war; particularly in the longer-term in post-conflict situations in which interventions need to be sustained and adapted over many years.
\end{abstract}

Keywords: War, Conflict, Developmental origins, Children, Mental health

\section{Background}

The adverse effects of war on the health of children have been well documented [1-4], but less well known is how exposure to violence can propagate effects across generations. Conflict causes injury, illness and breakdown in the structures that provide preventive, curative and ameliorative care. It has profound effects on society that form a permissive framework for the effects we describe. The mediators of loss are many, but include population displacement and breakdown of health services and schooling, on a background of economic decline and supply constraint. Figure 1 shows how these indirect effects are related with conflict and have a pervasive influence that reaches down to the next generation.

Conflicts or wars, as defined by the World Health Organization $^{\mathrm{a}}$, are becoming increasingly complex and involve multiple state and non-state actors [6]. In the last 20 years, conflicts have occurred in $37 \%$ of countries. In 2010, there were 30 armed conflicts involving at least one state, 26 non-state conflicts and 18 armed groups involved in one-

\footnotetext{
* Correspondence: d.devakumar@ucl.ac.uk

IInstitute for Global Health, University College London, London, UK

Full list of author information is available at the end of the article
}

sided violence $[7,8]$. It is difficult to know if the nature of conflict has changed, but recent wars provide evidence of the targeting of health facilities to weaken opposition forces and populations. Even schools are coming under attack, either deliberately or as collateral damage $[9,10]$. The association between conflict and poverty means that conflict-affected populations face major challenges after fighting has ceased. Economic development is affected by war in a number of ways that involve a combination of reduced output and increased expenditure, for example on security, and weakened systems of governance [11]. Most modern wars are short-lived and occur within national boundaries, but some, such as recent conflicts in South Sudan and Afghanistan, continue for decades [6]. Economic breakdown within conflict-afflicted states makes some countries among the poorest in the world, with approximately a third being defined as low-income (gross national income per capita <US\$995). The World Bank judges that $80 \%$ of the world's 20 poorest countries have experienced major conflicts [12], and it has been estimated that conflict leads to a reduction in annual economic output of $1 \%$ to $3 \%[13,14]$. 


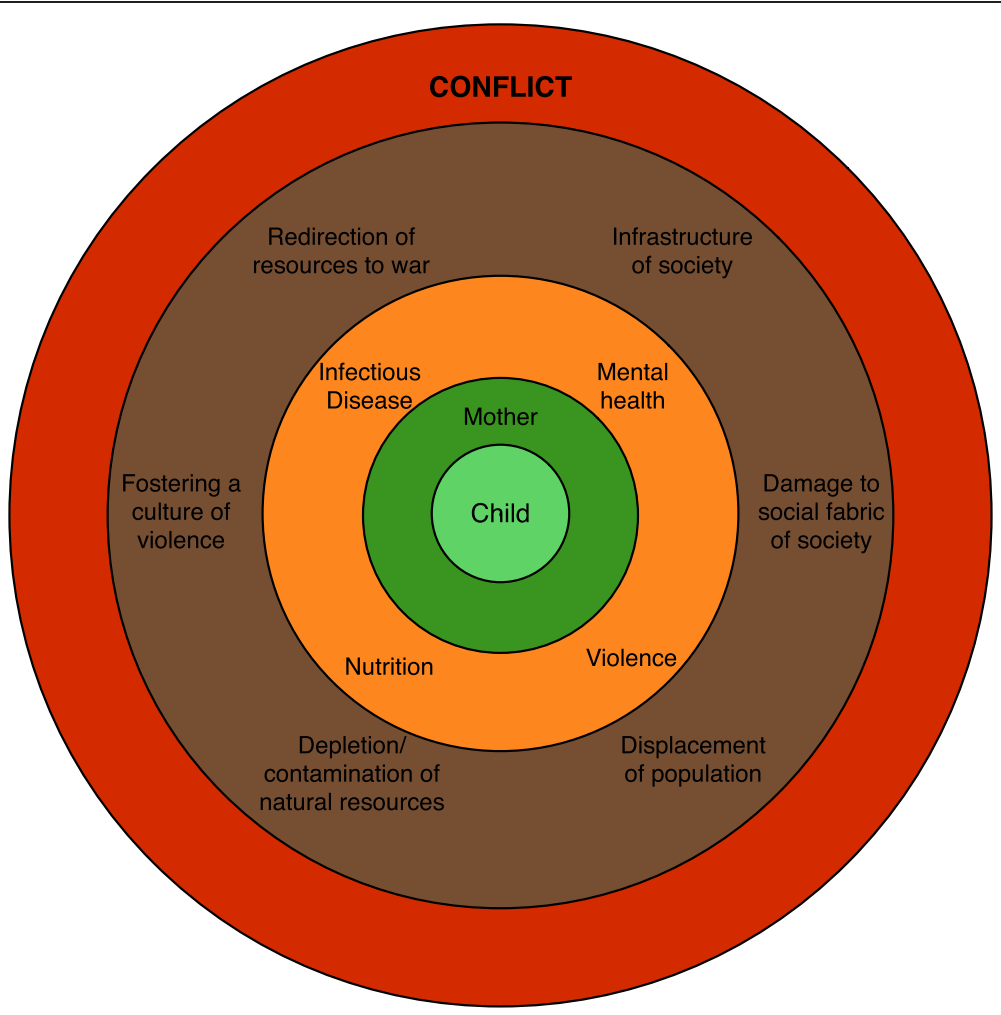

Figure 1 Direct effects (orange) and indirect effects- as described by Levy [5] - (brown) of conflict on mother and child.

That harms to health may be long-lasting within an individual's lifetime is well established, but there is increasing awareness that adverse effects may continue through intergenerational biological mechanisms. Our life course is sensitive to the environments in which we, our mothers, and grandmothers were conceived and grew up. Many exposures during development are mediated by maternal phenotype and reflect stresses to which mothers were originally exposed. Figure 2 illustrates how the effects of conflict can be mediated through harm to mothers. Recent work has emphasized that maternal physiology and behavior can buffer their offspring against ecological stresses, but this is only partial [15], such that exposure to conflict in one generation may potentially propagate adverse effects to subsequent generations. Epigenetic modifications to DNA expression have emerged as key biological mechanisms contributing to such intergenerational transmission, although direct transmission of epigenetic marks themselves appears rare and the primary impact of maternal phenotype is its influence on de novo marks in the offspring $[16,17]$.

Greater awareness of the potential intergenerational consequences of conflict may lead to their early recognition and improved diagnosis and response. Documentation of the consequences will also add to the overall evidence on the effects of conflict on health, which may

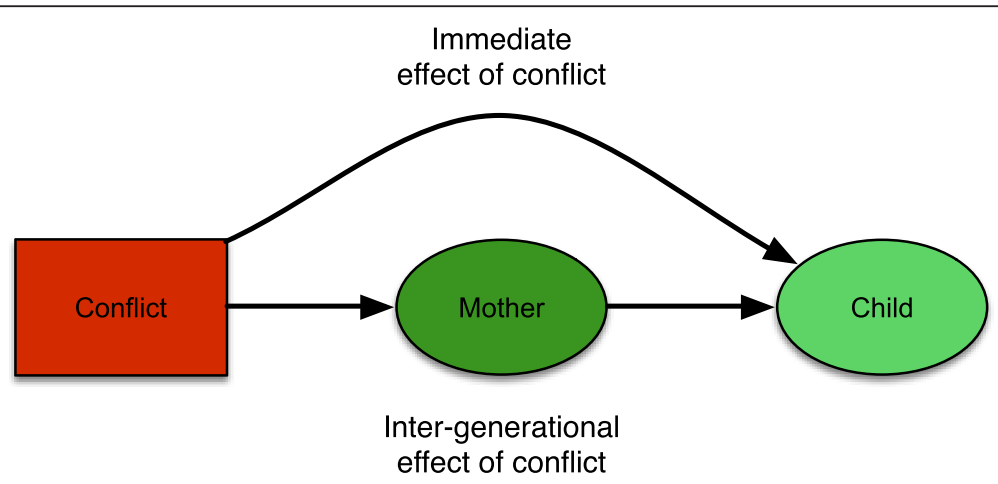

Figure 2 Immediate and intergenerational pathways through which conflict affects health. 
weigh more heavily in the balance when violent conflict is an option. A war may end, but its effects do not, and - in an example of intergenerational justice - those who resort to conflict may be held accountable for harms to the health of future generations. For this review, we searched the Medline, Psychinfo and Google Scholar databases using the search strategy described in Additional file 1. Only articles published in English were included, with no date restrictions. After finding an article, we considered the reference list or suggested articles for further evidence. This was supplemented by a general search of the literature on conflict/war and specific searches as questions arose. We summarize the evidence of how four features of conflict - violence, challenges to mental health, infections and malnutrition - may harm more than one generation, responding to emerging ideas about the epigenetic transmission of physiology $[18,19]$. We also discuss the multiplicative effects of ongoing conflict when hostilities are prolonged.

\section{Violence \\ Maternal exposure}

Violence is ubiquitous in war and pervades all strata of society, although its occurrence is probably underestimated [20-22]. The 20th century saw a secular trend toward a greater proportion of civilians affected, especially women and children [23]. It is estimated that up to $90 \%$ of war-related deaths in the last decade were civilian [5]. Conflict creates an ecosystem that persists, but is maladapted to peacetime, and its legacy is frequently an environment that fosters violence. Numbers of small arms remain for years, an example being the 1996 civil war in Guatemala, where rates of gun violence were greater after the war ended [24]. Similarly, increasing armed conflict in land disputes in East Africa is a consequence of prior cold war politics [25], and the 110 million landmines currently thought to remain in 68 countries [26] may lie dormant and harm civilians, both physically and mentally, decades after the original conflict [27,28].

Women are at particular risk of combatant and civilian injury, and of interpersonal violence. Violence against women increases in times of conflict through targeted acts, such as rape and domestic or intimate-partner violence. Sexual violence, including rape, assault, trafficking and prostitution, increases during many conflicts due to the breakdown of traditional safety structures [29]. It may also be used as an intentional strategy of domination, as reported in the former Yugoslavia and Rwanda $[20,30]$. The magnitude of sexual violence in conflict zones is difficult to quantify and tends to be underreported [31]. Approximately half of a sample of women interviewed in Liberia had suffered sexual violence [21] and studies in East Timor and Kosovo showed increases to $23 \%$ and $15 \%$, respectively, during conflict, compared to $10 \%$ and $2 \%$ in the post-conflict period [32,33]. A 2006 study from Lebanon suggested that domestic violence increased in areas where there was collective violence [22]. There are other, more complex, links. Substance use is associated with violence against women in non-conflict settings [34-36], although the evidence that it increases during conflict is limited. Clearer is the bidirectional association between violence and alcohol use [37-39].

\section{Intergenerational associations}

A clear example of an intergenerational effect is stillbirth after physical violence against a pregnant woman [40,41]. During the siege of Sarajevo, perinatal mortality and morbidity more than doubled, and there was a rise in congenital malformations from $0.4 \%$ to $3 \%$ [42]. Violence is also associated with an increase in premature birth [43], as was seen during the war in Croatia in the early 1990s [44]. Similar to this in non-conflict settings, a meta-analysis on abuse during pregnancy showed an increased odds ratio for low birth weight of 1.4 (95\% confidence interval (CI) 1.1 to 1.8$)$ [45].

Sexual violence has both short- and long-term effects. In the short-term, it is associated with an increase in sexually transmitted diseases, the intergenerational effects of which are discussed later. Maman and colleagues relate HIV infection to violence through three mechanisms: 'forced or coercive sexual intercourse with an infected partner; by limiting women's ability to negotiate safe sexual behaviors; and finally by establishing a pattern of sexual risk taking among individuals assaulted in childhood and adolescence' [46]. Even when services are available, fear of violence may lead to a lower likelihood of accessing treatments to prevent mother-to-child transmission of HIV [47]. In the longer-term, sexual violence may affect parenting capacity. In Rwanda and Darfur, children born after rape have been shown to be at increased risk of neglect, abuse, malnutrition and abandonment [48]. Evidence from hospitals in South Kivu, Democratic Republic of Congo, suggests that when children are born from rape, their mothers are five times more likely to suffer isolation from the community (odds ratio (OR) 4.84; 95\% CI 1.41 to 19.53) [49]. Children may also be victims of sexual violence [9], which may change its characteristics in times of conflict: a greater likelihood of gang rape was seen, for example, during conflict in the Democratic Republic of Congo. Sexual violence against children has profound effects on their mental and physical development, with implications for future pregnancies and relationships [50]. Mental illness, affecting a family's ability to function, can persist long after conflict has ended: symptom rates in those who had suffered from mass violence remained elevated for a decade after the Cambodian conflict [51]. More generally, exposure to violence has been associated with long- 
term effects on children's health, brain structure and neural function [52]. A violent environment may also have long-term effects on the maturational schedule. In Colombia, the secular decline in age at menarche accelerated during periods with high homicide rates, suggesting that psychosocial cues can alter the developmental trajectory [53].

Violence can affect family life, both economically and socially. Among Cambodian families in which one member was injured by a landmine, $61 \%$ were pushed into debt [54]. A study from Nicaragua found that women who suffered from abuse had $44 \%$ lower earnings [55]. Combat, death and displacement can also lead to the breakdown of family structures. Family members may shift roles, as was noted among women in Nepal who became combatants and replaced those lost during the conflict [56].

It is generally thought that experiencing violence as a child is a risk factor for committing child abuse as an adult [57]. There is some evidence that children who witnessed frightening events (for example, in the Spanish civil war of 1936) are 'more immune to the horrors of violence' [4]. This is especially so for child soldiers, who may experience dehumanizing conditions during a formative period, but there is a danger that maladaptive behaviors are passed on to the next generation. There are few long-term studies in this group. In a 16-year followup of child soldiers in Mozambique, men still suffered distress from their traumatic events, but there was no evidence that abusive relationships were passed on to their children [58].

Chemical or radioactive weapons can also damage future generations. While evidence of genetic effects of radiation on the children of survivors of atomic bombs is lacking, follow up studies have found evidence of severe learning difficulties and microcephaly in people exposed in utero. In utero exposure was also associated with decreased school performance and intelligence quotient (IQ) [59,60]. Case-control studies suggest that exposure of men to mustard gas in Iran and mineral contamination (particularly depleted uranium) in Iraq was associated with congenital abnormalities in their children $[61,62]$.

\section{Mental health \\ Maternal exposure}

Mental health conditions are common during conflicts, and are augmented by the breakdown of mental health services and community coping strategies, and by increases in stress levels and drug and alcohol use [63]. The most common conditions are depression, anxiety and psychosomatic disorders, but the most widely studied in relation to conflict is post-traumatic stress disorder (PTSD). PTSD is common among combatants, and child soldiers are known to suffer from a much higher than average incidence of psychological disturbances and mental illness [64-67]. PTSD is also found in civilian populations in both women and children [68,69]. De Jong et al. showed that PTSD and anxiety disorder were the most common mental illnesses in all populations, and exposure to violence increased their likelihood in the four conflict zones of Algeria, Cambodia, Ethiopia and Palestine [70]. In Kabul, mothers of children under five were found to have an increase in prevalence of PTSD from 10\% to 53\% if they experienced at least one armed conflict event [71], and women living in conflict areas in Bosnia and Herzegovina showed a sevenfold increase over a control group in PTSD prevalence [72]. Importantly, mental health disorders also rise in those not directly exposed to violence. Women are generally affected more than men and strong associations exist between the mental health of mothers and their children [63]. For example, in Algeria poor quality of camp housing and the general difficulties of daily living were both associated with increased odds of PTSD (OR 1.8, 95\% CI 1.3 to 2.5 and $1.6,95 \%$ CI 1.1 to 2.4 , respectively) [73]. Mental illness is also common in children. A systematic review in a long-term conflict in the Middle East showed that children do suffer from a wide range of mental disorders, such as PTSD, depression, anxiety, functional impairment, behavioral problems and Attention Deficit Hyperactivity Disorder [74].

The evidence on drug use in conflict is partial. Drug use increases in groups that have been displaced, especially among combatants and former combatants, for which it may be a way of coping with traumatic situations or memories [75-78]. Economic pressures and increased availability can lead to a rise or change in drug use. For example, the conflict and related drug policy in Afghanistan have been linked to an increase in intravenous opiate use $[79,80]$. The pattern of illicit drug use depends on the setting: opiates are more common in Pakistan and Afghanistan, while benzodiazepines are common in Bosnia-Herzegovina [81]. A study of khat (a substance that contains a psychoactive compound similar to amphetamines) in north-west Somalia showed that recent use among ex-combatants was $60 \%$, compared with $28 \%$ in civilian war survivors and $18 \%$ in civilians with no experience of war. Psychotic symptoms were linked with age of onset of khat use and binge consumption. Rates of severe disability due to mental disorders (primarily psychosis) in males over the age of 12 increased in relation to their experience of war, with a prevalence of $16 \%$ in excombatants, $8 \%$ in civilian war survivors and only $3 \%$ in those with no experience of war [82].

\section{Intergenerational associations}

While evidence is currently limited, parental trauma and psychosocial stress during conflict have been associated 
with adverse health effects in offspring, through both biological pathways (such as neuroendocrine and immune system modulation) and propagation of stressful social environments [83-85]. Stress may be a mediator through which parents transmit adverse effects to their children, in both conflict and non-conflict settings. In a large population-based cohort study, maternal stress during pregnancy was associated with a number of outcomes in children, including risk of infection and mental disorders [86]. Stress arising from childhood separation from parents during World War II was linked to longterm impairment in offspring social mobility and socioeconomic position [87]. A study in people living near Gaza showed a strong association between maternal symptoms of depression, anxiety and PTSD, and PTSD symptoms in children. Avoidance behaviors in children were also associated with the degree of trauma exposure in the mother [88], similar to associations shown in animal studies [89]. Possible mechanisms include epigenetic changes in the hypothalamic-pituitary-adrenal axis (see Box 1) $[90,91]$. There is also some evidence that paternal PTSD can likewise lead to symptoms in children [92].

Stressful emotions can be passed from one generation to the next, but maternal buffering appears to provide an important damping effect, so that children are less

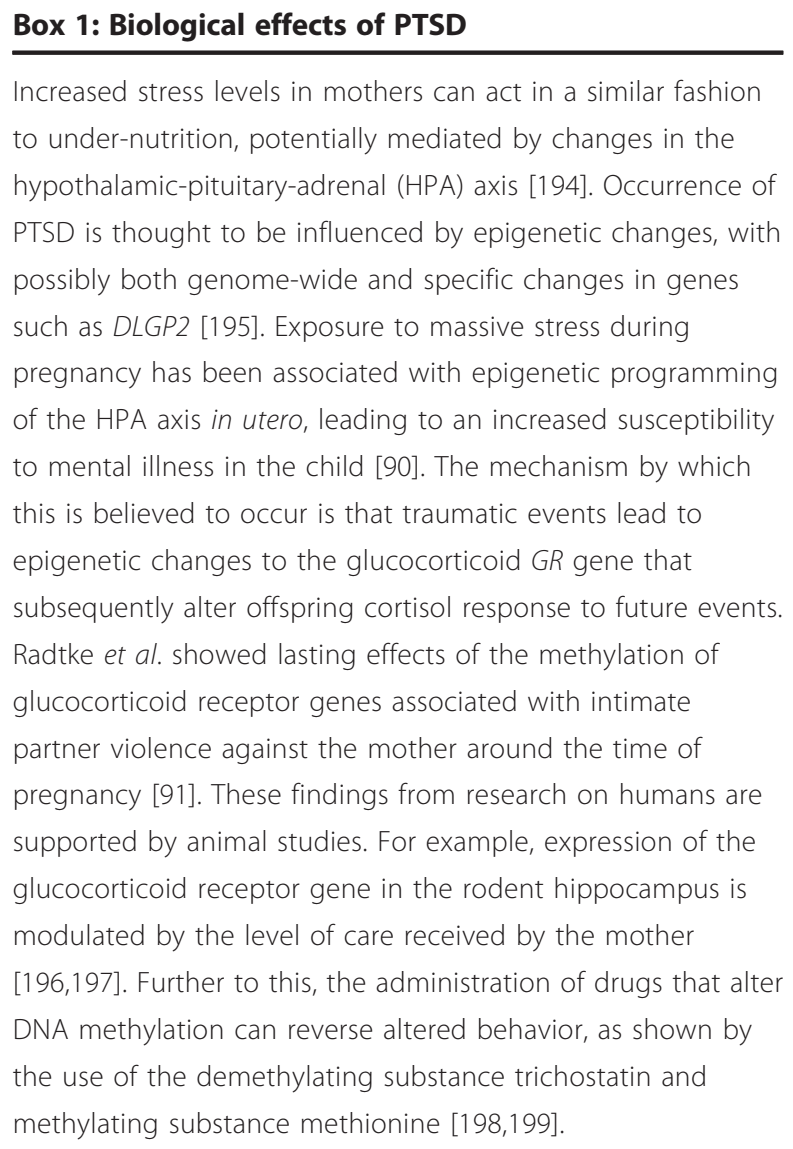

affected than their parents. Children exhibit a form of resilience [93] that is related in turn to their mothers' wellbeing, quality of caregiving and environmental support [94], but traumatic events, such as those occurring in a conflict, may override this buffering. For example, children of Australian veterans of the Vietnam war were found to have a suicide rate three times that of the general community [95] and elevated rates of PTSD and other mental illness have been described in the offspring of Holocaust survivors [96-100]. Mothers, but not fathers, who were themselves offspring of Holocaust survivors had 'higher levels of psychological stress and less positive parenting', while in the grand-offspring generation, children had less positive self-perception and were said by their peers to show 'inferior emotional, instrumental, and social functioning' [101].

There is also evidence of intergenerational mental health effects in non-conflict settings, and these are likely to be exacerbated by conflict. A meta-analysis by Surkan et al. showed that maternal depression or depressive symptoms were associated with an OR of 1.5 (95\% CI 1.2 to 1.8$)$ for children being underweight and 1.4 (95\% CI 1.2 to 1.7) for stunting. The reasons for this include poorer antenatal care, increased risk-taking behaviors and impaired maternal caring [102], with reduced or early cessation of breastfeeding as one possible mediator [103,104]. Maternal mental illness has also been linked to children's cognitive abilities [105]. In India, maternal common mental disorder was associated negatively with mental development in infants at six months of age [106] and, in Barbados, with cognitive outcomes [107]. The latter association persisted when assessed via a school entrance exam at 11 to 12 years of age [108].

There are several mechanisms whereby drug use may exert adverse intergenerational effects. Drug use by pregnant women can have transplacental effects or cause maternal ill-health or altered behavior. The manifestations may be acute - neonatal abstinence syndrome from opiate withdrawal, for example [109] - or lead to longer-term behavioral and cognitive changes [110]. Both drugs and alcohol are closely associated with mental illness in the user, which, in turn, can have detrimental effects on parenting ability and employment. The use of khat has been linked to mental illness, as well as affecting the reproductive system and being teratogenic [111]. However, the magnitude of the intergenerational effect of drug use associated with conflict remains to be established.

\section{Infectious diseases and health systems Maternal exposure}

Mortality in women and children during conflicts is predominantly the result of conditions related indirectly to 
violence: infectious disease, malnutrition and complications of pregnancy [8]. With the exception of a few examples for which limitation of movement has appeared to prevent transmission [112], higher rates of infectious diseases, such as shigellosis and cholera, are common in conflict zones [113,114]. As described in Table 1, the major drivers are movement of people, infrastructural deterioration, and breakdown in prevention and treatment [115]. Migration of people, for example, both increases infectious disease burden and exposes unimmunized populations to new pathogens.

Sexual violence against women has been mentioned, and sexually transmitted infection rates may rise in conflict settings, as seen with syphilis and gonorrhea in the Second World War [129]. Increased infections are especially common in refugee or IDP populations [130], and in situations characterized by alcohol use and riskier sexual practices [75]. They have also been linked with psychiatric conditions and psychosocial factors. In waraffected Eastern Uganda, major depressive disorder and sexual torture were associated with high-risk sexual activities, which were themselves associated with HIV transmission [131]. It is thought that the conflict in Mozambique led to higher rates of syphilis in pregnant women, some of whom experienced sexual abuse and repeated rape while being held by the insurgents [132] HIV rates may also be augmented by untreated sexually transmitted infections, lack of condoms, increased incidence of sex work and lack of health education $[80,119]$. An estimated $70 \%$ of Rwanda's rape survivors were infected with HIV [133].

\section{Intergenerational associations}

Infectious diseases can affect subsequent generations through direct effects on pregnant women or through the effects of long-term morbidity on their future health, reproductive capacity and finances. The Spanish influenza outbreak, which resulted in up to 40 million deaths, is considered to have originated in and been exacerbated by the conditions of the First World War [134,135], and

Table 1 Common reasons for an increase in infectious diseases during conflict

Causes of an increase Mechanisms of action Examples

in infectious disease

Increased burden of Migration leads to the migration of infectious diseases disease infecting new non-immune hosts.

Breakdown of prevention programs leading to an increase in vector-borne diseases, such as malaria and trypanosomiasis. Susceptibility of the
population to infectious diseases

Breakdown of the healthcare system
Reduced immunity from malnutrition, inadequate coverage of immunizations and the loss of herd immunity and the lack of innate immunity to unseen infective organisms.

Healthcare may be suspended or diminished [2] and funds diverted from it to armed forces or security actors. This leads to reduced detection and treatment of infectious diseases and potentially to increased rates of antibiotic resistance. This is combined with difficulties in accessing the services that do function due to fear of movement or breakdown of the transport networks.

Movement of healthcare workers
The United Nations High Commissioner for Refugees (UNHCR) estimates that there are 15.3 million refugees and a further 26 million internally displaced persons (IDPs) worldwide [116]. Migration in camps that are overcrowded leads to situations where sanitation is not adequate and outbreaks can occur [117], a consideration going back nearly a century to the start of World War II [118].

Afghanistan has seen an increase in malaria after it had successfully controlled this disease in the 1970s and the Democratic Republic of Congo has had a rise in trypanosomiasis in conjunction with the rise in conflict [119]. Refugee camps in Sierra Leone and Guinea have both seen outbreaks of Lassa fever from the infestation of rodents $[120,121]$.

Afghan refugees from a malaria-free region who fled to Pakistan in 1981 had a prevalence of malaria more than double that of the local population, and a ten-fold increase in burden over the following decade [122].

The restriction of transport networks by the Maoist rebels in Nepal in 2005 held up the supply of vaccines, vitamin A, and deworming drugs to nearly 3.6 million Nepalese children [123].

Even normally functioning immunization programs can be affected by security concerns, the polio eradication program in Afghanistan being an example [124]. During the conflict in Bosnia and Herzegovina in the early 1990s, immunization rates fell from approximately $95 \%$ pre-conflict to around 30\% [125]. Health facilities may themselves come under deliberate attack $[8][124,126]$. In the Nicaraguan conflict of the mid1980s, approximately a quarter of the health facilities were partially or completely destroyed [54].

Healthcare workers often have the socioeconomic wherewithal to migrate during conflicts. A report from the International Committee of the Red Cross quotes an Iraqi Ministry of Health estimate that 18,000 of the country's 34,000 doctors left [127]. Liberia is thought to have seen a decrease from 237 to 20 doctors during recent conflict [128]. 
research on prenatal exposure suggests both long-term health costs, such as increased rates of cardiovascular disease and potentially increased disability, and economic penalties [136,137]. More specifically, infection in utero may lead to abortion or congenital malformations, and many infections can trigger premature birth. A fall in immunization rates may be accompanied by reductions in herd immunity: outbreaks of rubella, which can lead to severe congenital abnormalities, occurred during the conflict in Bosnia and Herzegovina [138]. Congenital infections lead to impaired cognitive development, respiratory and gastrointestinal disease, and may leave children vulnerable to infections during their lifetime [139].

Infections such as HIV and syphilis can be transmitted vertically from mother to child, causing acute infections, fetal or infant death or chronic childhood conditions. A review of neurodevelopmental outcomes showed that vertical transmission of HIV was associated with poorer neurodevelopmental outcomes in children from resourcepoor countries [140]. Likewise, repeated malarial infections and continuing parasitemia are associated with reduced cognitive ability in children in the short- and long-term, with effects on their future economic capacity [141-143].

Lack of human resources adversely affects any future health system. Conflict-driven collapse of the education system, for example, reduces the pool of people who could become health workers. The best-known example is the breakdown of the education system under Cambodia's Khmer Rouge regime, in which teachers were systematically imprisoned or executed. This not only affected the education of children at the time, but also led to a longerterm loss of knowledge and skills from society.

As common users of healthcare services, pregnant women are especially vulnerable to healthcare service disruptions, leading to the exacerbation of illness. An example of this would be the disruption to the supply of drugs and other medical equipment, as described in northern Sri Lanka during the recent civil war. Obstetric complications, such as pre-eclampsia, were common, potentially contributing to the higher rate of low birthweight that was found [144]. In Palestine, military checkpoints delaying access to maternity facilities were associated with an increase in home births from $8 \%$ in 1999 to $33 \%$ in 2002 [145], while in Nepal's recent civil war, disruption of a hospital's electricity supply led to Caesarean sections being performed by torchlight [123]. More generally, maternal mortality rises during conflict. About half the countries suffering from conflict have maternal mortality ratios $>200$ per 100,000 live births [8]. The maternal mortality ratio during the conflict in Bosnia and Herzegovina was approximately $75 \%$ higher than in the periods immediately before and after [146]. A catastrophic event in its own right, maternal mortality also has damaging effects on the remaining family members, particularly children. Evidence from a non-conflict area of Bangladesh shows very high mortality among younger children - up to $70 \%$ for a surviving neonate within two years of the maternal death - approximately 10 times higher than if neither parent had died. Higher mortality persists in children five- to ten-years old, for whom the probability increases five-fold [147]. Similar evidence from Haiti shows increased odds of mortality after a maternal death of $55 \%$ for children younger than 12-years-old [148].

\section{Nutrition \\ Maternal exposure}

Malnutrition is common in conflicts and is predominantly manifest in children [149]. During a recent famine in the Horn of Africa, rates of global and severe acute malnutrition reached levels of $50 \%$ and $35 \%$, respectively [150]. Food security falls during conflict for reasons ranging from reduced crop production to breaks in the supply chain and trade restrictions [9,151]. Food resources may be destroyed deliberately as a means of harm or population control: in 1980, 140,000 hectares were destroyed by Ethiopian government forces to prevent their use by rebel groups [152]. The diversion of resources away from healthcare and food supply to military expenditure in war can adversely affect population health. Despite an increase in overall gross development product per capita, the early Nazi regime saw an increase in mortality and a decline in child height [153]. International sanctions, a favored government response to civil conflict, may generate similar effects. Neonatal mortality, for example, increased substantially in Iraq during the 1990s [154].

There is some evidence that breastfeeding rates can decline in war times and the adverse effects of this can be greater. In the war in Croatia in the early 1990s, breast-feeding duration was found to be shorter in affected areas [155]. In Guinea Bissau in the late 1990s, infants who were weaned earlier during war periods had higher mortality rates than breastfed infants compared to the pre-war years where this difference was not present [156]. In addition to not having breast milk, we would postulate that disruption to formula milk supplies and unclean water would compound the adverse effects. It was shown that children who were never breastfed were more likely to be malnourished [157].

War may contribute to either acute malnutrition and increased mortality or chronic malnutrition leading to stunting and subtle prolonged deficits associated with lower school attainment and reduced adult income [158]. Nutritional deficiencies may be in macronutrients, providing the basic energy and substrate for growth, or in micronutrients, including vitamins and minerals that promote cellular function. Micronutrient deficiency 
diseases are common in conflicts: scurvy in Afghanistan from vitamin C deficiency [159], pellagra in Angola from niacin deficiency [160].

\section{Intergenerational associations}

Malnourished mothers pass on the stress to their children, whose poor nutritional status may affect subsequent generations. In the Dutch Hunger Winter of 1944 to 1945 during the German occupation, maternal undernutrition was associated with increased risk of low birth weight [161]. Although not directly attributed to malnutrition, a higher proportion of babies were born with moderate low birth weight in Croatia during the war period (1991 to 1995) [162]. Low birth weight is the strongest risk factor for mortality in early infancy [163] and is associated with reduced educational attainment and physical work capacity [158]. Subtler effects include maternal micronutrient deficiencies, such as iron deficiency anemia [164], and conditions that directly affect the fetus, such as neural tube defects associated with folate deficiency [165]. Prenatal malnutrition, leading to low birth weight, results in lower subsequent height and lean mass [166]. Short maternal stature is associated with an increased risk of gestational diabetes, macrosomia, and birth injury and shorter gestation [167-169]. Among Hmong refugees from the Second Indochina war, children displaced during infancy were shorter as adults, whereas children born during the war were found to have greater adiposity, particularly central adiposity [170]. Such growth penalties may take generations to resolve. Maternal short stature is a risk factor for obstructed labor, Caesarean section and low birth weight [171-173], potentially generating a long-term intergenerational cycle [15]. Contrasting with sperm production in men, women's ova are formed primarily early in life, and damage to the reproductive system in young girls, from infections, trauma or harmful substances, for example, can have long-term effects on their reproductive capacity and their children $[174,175]$.

Peri-conceptional, fetal and infant malnutrition can affect the risk of non-communicable disease. People exposed to maternal malnutrition in utero during the Dutch Hunger Winter showed increased risk of obesity, hypertension, cardiovascular disease and type 2 diabetes [176-178]. The longer-term effects depended on when in gestation the lack of nutrition occurred and the period for which there was a deficit, and there is some evidence for a difference in the long-term effects between male and female offspring $[179,180]$. Although the evidence is conflicting, it may be that the detrimental effects of the Dutch famine extended into the following generation, with the offspring of women born in the famine found to have a lower birth weight $[161,181]$. Similar associations between early-life famine exposure and subsequent elevated chronic disease risk were reported following the Biafran conflict of 1968 to 1970 [182], and the Chinese famine of 1959 to 1961 [183-186]. In the latter, early-life exposure was also associated with increased risk of schizophrenia [187,188]. In non-conflict settings it is common for chronic disease in adults to affect their offspring, both biologically and economically via loss of earnings. An example of this would be the propensity to obesity and the development of gestational diabetes leading to preterm birth and macrosomia.

Deliberate military efforts may not only impair the capacity for food production but also increase exposure to toxins. For example, bombing and Agent Orange were used in Vietnam to 'deny the enemy sources of food and means of cover' [189]. Approximately 11 to 12 million gallons of Agent Orange were sprayed over nearly 10\% of South Vietnam between 1961 and 1971. While research on intergenerational effects continues, the WHO describes dioxin, the active element of Agent Orange, as 'highly toxic' and able to cause 'reproductive and developmental problems' [190,191].

\section{Multiplicative effects}

The intergenerational harms of short conflicts are mitigated by post-conflict recovery of economies, societies and health and schooling systems. In long-lasting conflicts, however, they are exacerbated by on-going fighting to produce a composite effect whereby the immediate effects of conflict combine with long-term and intergenerational effects, as illustrated schematically in Figure 3.

It is difficult to provide definitive evidence for this as prior susceptibility is hard to quantify, but we propose two illustrative scenarios. In the first, an increase in preterm births, perhaps associated with an increase in congenital infections, makes children more susceptible to subsequent infection. This susceptibility is exacerbated by the increased wartime burden of disease. Infection exacerbates wartime under-nutrition, which combines with reduction in the food supply in a downward spiral that reduces a child's capacity to cope with physical insults. These multiple deficits occur within a health system that already cannot cope. In the second scenario, children growing up in a long-lasting conflict region suffer from the intergenerational effects of mental illhealth, as well as an ongoing conflict stress burden. For example, a child inherits an impaired cortisol response through parental stressful experiences, and this makes it harder to cope with the subsequent stressful events the child faces herself.

\section{Discussion}

We have given examples of how conflict can have longlasting intergenerational effects, working through parental 


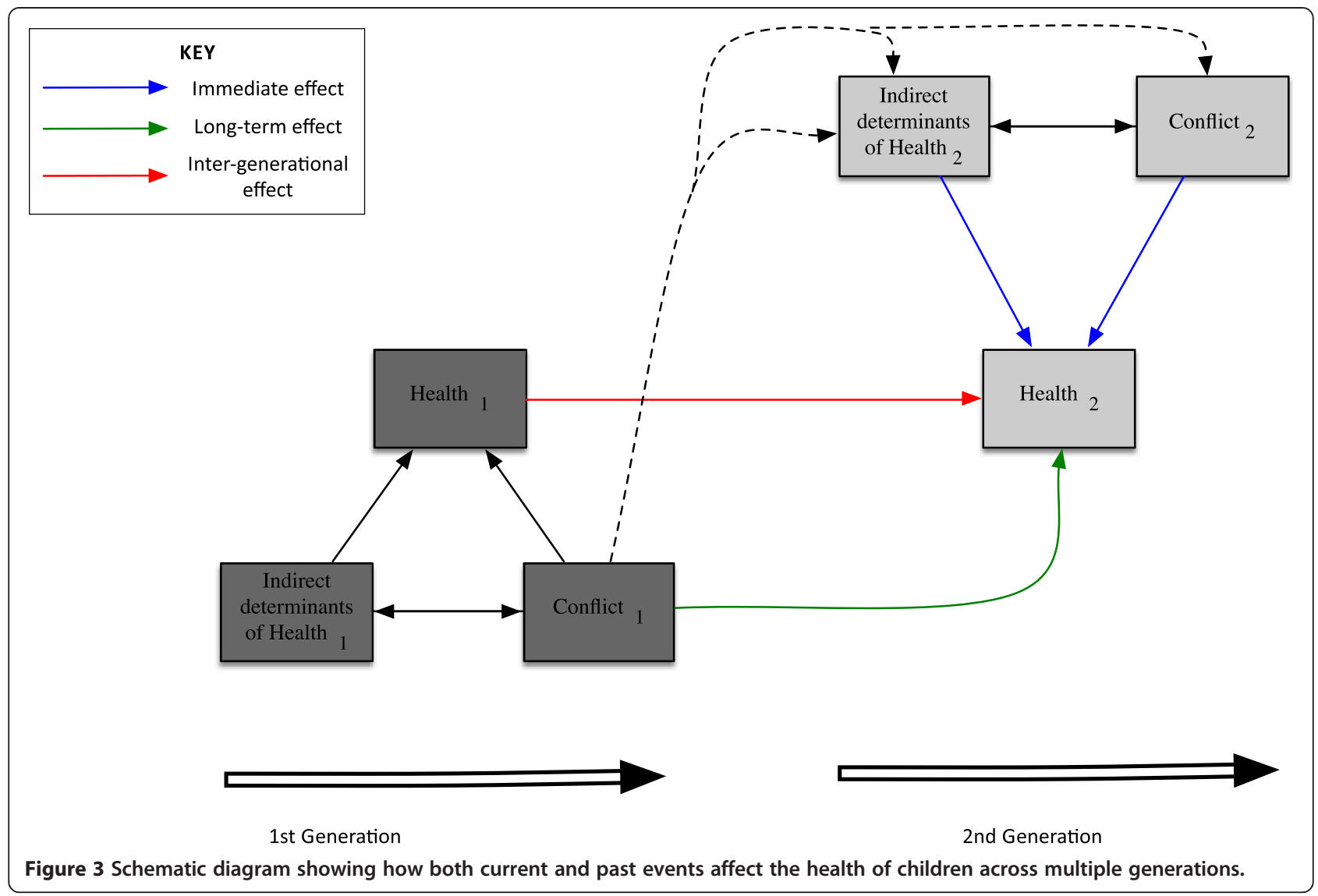

exposure to violence, mental health stressors, infection and nutrition (summarized in Table 2). Much has been written about the health effects of war but the literature on its enduring effects is sparse. With our growing understanding of the developmental origins of health and disease, it is becoming evident that the extreme conditions that conflict imposes can have effects that last for generations, making a 'brief' conflict a misnomer. Many interrelated pathways have been identified between parental exposure and subsequent generations, but further evidence is required to estimate the magnitude of their effects. Given the range of conflict scenarios, there is likely to be a great deal of heterogeneity.

Our categorization of potential exposures and effects is illustrative and artificial in the sense that their interactions are complex. Physiological and pathological effects of stressors - trauma, infection, malnutrition - are linked in a complex system with institutional factors, such as education and health system challenges, and social factors, such as cultures of alcohol use and violence. Prior conflict creates a population with a reduced capacity to cope with adversity, and ongoing or subsequent conflict may compound this and exacerbate the adverse health effects. The prevention of conflict and its effects on health are crucially important public health concerns [11], but the intergenerational picture has received little attention so far. In many cases, the causal link between conflict and intergenerational outcomes is lacking, and the paucity of research reflects at least partly the challenges of working in current or recent conflict zones. Where evidence from conflict situations is limited, we have hypothesized on the basis of available evidence or discussed evidence from non-conflict situations.

\section{Intergenerational justice}

Similar to the growing calls for consideration of future generations in climate change debates, we call for policy makers to consider them with respect to conflict. The notion of intergenerational justice emphasizes a temporal dimension, giving future generations rights that those currently alive should maintain. The extent to which existing legislative powers can be used to uphold these rights is uncertain, but legal bodies could potentially extend their scope to the violation of the rights of future beings. Statutes such as the UN Convention on the Rights of the Child (Articles 38 and 39) already exist to protect the rights of children in war [192]. The 
Table 2 Summary of maternal and intergenerational effects

\begin{tabular}{|c|c|c|}
\hline Key areas & $\begin{array}{l}\text { Maternal } \\
\text { exposure - possible } \\
\text { consequences }\end{array}$ & $\begin{array}{l}\text { Intergenerational } \\
\text { associations - increased } \\
\text { risk of }\end{array}$ \\
\hline \multirow[t]{6}{*}{ Violence } & Domestic violence & Congenital malformations \\
\hline & $\begin{array}{l}\text { Mental illness/physical } \\
\text { trauma }\end{array}$ & Low birth weight \\
\hline & Rape & $\begin{array}{l}\text { Perinatal morbidity and } \\
\text { mortality }\end{array}$ \\
\hline & \multirow{3}{*}{$\begin{array}{l}\text { Trafficking and } \\
\text { prostitution }\end{array}$} & Premature birth \\
\hline & & $\begin{array}{l}\text { Altered physical and } \\
\text { mental development }\end{array}$ \\
\hline & & Neglect and abuse \\
\hline \multirow[t]{7}{*}{ Mental health } & PTSD & Impaired growth \\
\hline & Depression & $\begin{array}{l}\text { Poor educational } \\
\text { attainment }\end{array}$ \\
\hline & Anxiety & $\begin{array}{l}\text { Neuroendocrine and } \\
\text { immune system } \\
\text { modulation }\end{array}$ \\
\hline & $\begin{array}{l}\text { Psychosomatic } \\
\text { disorders }\end{array}$ & Infection \\
\hline & \multirow[t]{3}{*}{ Drug and alcohol abuse } & Mental illness \\
\hline & & Higher suicide rates \\
\hline & & $\begin{array}{l}\text { Social functioning } \\
\text { impairment }\end{array}$ \\
\hline \multirow{5}{*}{$\begin{array}{l}\text { Infectious diseases } \\
\text { and health } \\
\text { systems }\end{array}$} & $\begin{array}{l}\text { Increased transmission } \\
\text { of infectious diseases }\end{array}$ & Fetal or infant mortality \\
\hline & Malnutrition & Disability \\
\hline & Obstetric complications & Cardiovascular disease \\
\hline & \multirow{2}{*}{$\begin{array}{l}\text { Increase in maternal } \\
\text { mortality }\end{array}$} & Congenital malformations \\
\hline & & $\begin{array}{l}\text { Impaired cognitive } \\
\text { development }\end{array}$ \\
\hline \multirow[t]{8}{*}{ Nutrition } & $\begin{array}{l}\text { Malnutrition including } \\
\text { micronutrient } \\
\text { deficiencies }\end{array}$ & Neonatal mortality \\
\hline & Obstetric complications & Low birth weight \\
\hline & \multirow[t]{6}{*}{ Maternal mortality } & Malnutrition/under-nutrition \\
\hline & & $\begin{array}{l}\text { Impaired growth and } \\
\text { development }\end{array}$ \\
\hline & & $\begin{array}{l}\text { Educational } \\
\text { under-attainment }\end{array}$ \\
\hline & & Congenital abnormalities \\
\hline & & $\begin{array}{l}\text { Non-communicable } \\
\text { diseases }\end{array}$ \\
\hline & & $\begin{array}{l}\text { Future reproductive } \\
\text { capacity }\end{array}$ \\
\hline
\end{tabular}

arguments we lay out are aligned with gender-based social justice since in many parts of the world women receive fewer resources in general and particularly in terms of access to healthcare [193]. The idea of intergenerational justice can also be aligned with a present day rights-based approach to help protect not only the current population but also future generations. In this sense, we do not see a clash between the two.

It is not within the scope of this paper to adequately review the interventions that may be of benefit in preventing the future adverse effects of war, but we have tried to summarize the main categories in Box 2. Many of these are the same as those required for the current population, but the imperative to protect certain groups, such as pregnant women, is reinforced. Past conflicts may have led to positive changes, such as the removal of oppressive regimes, as well as negative impacts. However, our discussion highlights the importance of minimizing the likelihood of conflict when seeking such positive changes. Interventions to break the cycle of transmission should be examined at the point at which governing bodies and non-state actors are considering going to war, and in its aftermath, as well as during conflict. In examining the health of a population, previous insults need to be considered in order to understand fully the situation and to initiate solutions. Importantly, policy makers should bear in mind that a population may take multiple generations for the adverse health effects of conflict to be negated as a region attempts to return to its premorbid state or moves on to a new postconflict one and it is possible that a return to the previous state may never happen if conflict changes the status quo within a given area. Conflict-related public health interventions need to be sustained for a number of years and adapted over time to cope with changing needs.

\section{Summary}

In this article, we summarize how the effects of war can propagate across generations. We hope this review will stimulate debate and research on the long-term and intergenerational health effects of conflict and their mechanisms and contribute to the discussion of the costs of war. The evidence we have included strengthens the position that violent conflict should be avoided and indicates that intergenerational effects should be included routinely in the anticipated and estimated consequences of war.

\section{Endnote}

${ }^{a}$ WHO definition of conflict: 'The instrumental use of [armed] violence by people who identify themselves as members of a group - whether this group is transitory or has a more permanent identity - against another group or set of individuals, in order to achieve political, economic or social objectives'. Wars are armed conflicts with more than 1,000 battle-related deaths in any one year. 


\section{Box 2: Using the evidence of intergenerational consequences of conflict: some possible strategies}

\section{Prevent the onset of war and violent conflict}

When conflict starts, all options to reach an alternative peaceful solution have rarely been exhausted [200]. There may be strong political or economic motivations behind the decision to go to war or resort to violent conflict. These may include the need to do so for 'humanitarian' reasons, although recent military action initiated on this basis has caused such a degree of mortality, morbidity and destruction that the humanitarian reason has been rather discredited. However, there is potentially a case to be made for going to war to prevent death, injury and destruction.

Viewed objectively, there will be a range of reasons for going to war or taking violent action and a range of reasons for not doing so; evidence of the health consequences of taking violent action will fall within the latter. The greater this evidence is, the harder it will be to justify war. Intergenerational consequences for health are an under-researched result of war that could tip the balance against it, help put a brake on the push to war and ensure that other peaceful options are pursued as a priority.

\section{Factor in a longer-term perspective if contemplating going to war}

The link between the likely longer-term health consequences of going to war and the conflict itself can be hard to establish definitively. The more time passes, the more possible confounders have to be taken into account, making direct causal links difficult to prove. However, combining disciplines and research to illustrate these links in the area of child health can be compelling, as there is a general consensus that children should be protected during war and that future generations are innocent. This makes a growing body of evidence that supports the link between conflict and future health problems for children a strong advocacy tool for conflict prevention.

\section{Ensure a long-term component to interventions both during and after conflict, taking long term consequences into account}

The type of interventions used to meet health needs caused by conflict, and the resources that are dedicated to them, should be decided on the basis of need. Much work has been done on how those needs can be accurately assessed [201] and minimum standards of response assured [202]. If need can be shown to be more long-lasting and serious than previously thought, particularly in relation to mother and child health, it could influence needs assessments, minimum standards and intervention planning. This would also help make the case for sufficient and appropriate resource allocation.

\section{Ensure extra care is provided for vulnerable groups, particularly pregnant women}

Evidence of the intergenerational health consequences of violent conflict will reinforce the degree of vulnerability of pregnant women to health shocks. Pregnant and lactating women are already recognized as a priority group for humanitarian health programs [203], but there is still much to be done before programs are fully integrated, effective and adequately resourced. A better understanding of the consequences of not having optimal and well-resourced programs will be a strong advocacy tool to use with donors and others.

\section{Upholding international conventions to safeguard children through intergenerational justice}

International law that relates to the rights of children is almost universally recognized and key parts of it are considered to be customary law [204]. Better established links between violent conflict and the health and wellbeing of children not yet born could contribute to holding those who initiate war or violent conflict to account for the consequences of their actions. This, in turn, would be a further restraining factor on initiating violent conflict.

\section{Additional file}

Additional file 1: Supporting material: literature review method.

\section{Abbreviations}

Cl: confidence interval; HPA: hypothalamic-pituitary-adrenal; IDP: internally displaced person; OR: odds ratio; PTSD: post-traumatic stress disorder; UNHCR: United Nations High Commissioner for Refugees.

\section{Competing interests}

The authors declare that they have no competing interests.

\section{Authors' contributions}

$D D$ reviewed the literature and wrote the initial draft. $M B, D O, E S$, and JW critically reviewed and amended it. All authors read and approved the final manuscript.

\section{Acknowledgements}

Ruwan Ratnayake, The International Rescue Committee, advised on the content and commented on a draft version. There was no specific funding for this research. D Devakumar (092121) and D Osrin (091561) are supported by Wellcome Trust Research fellowships.

\section{Author details \\ ${ }^{1}$ Institute for Global Health, University College London, London, UK. ${ }^{2}$ Medact, London, UK. ${ }^{3}$ Royal Tropical Institute, Amsterdam, Netherlands. ${ }^{4}$ Childhood Nutrition Research Centre, Institute of Child Health, University College London, London, UK.}

Received: 6 October 2013 Accepted: 26 February 2014 Published: 02 Apr 2014

References

1. Southall D, Carballo M: Can children be protected from the effect of war? BMJ 1996, 313:1493. 
2. Goldson E: The effect of war on children. Child Abuse Negl 1996, 20:809-819. 3. Jensen PS, Shaw JO: Children as victims of war: current knowledge and future research needs. J Am Acad Child Adolesc Psychiatry 1993, 32:697-708.

4. Pearn J: Children and war. J Paediatr Child Health 2003, 39:166-172.

5. Levy BS: Health and peace. Croat Med J 2002, 43:114-116.

6. World Health Organization: World Report on Violence and Health; 2002 Available at: http://www.who.int/violence_injury_prevention/violence/ world_report/en/.

7. Stockholm International Peace Research Institute: SIPRI Yearbook 2012. Oxford: Oxford University Press; 2012.

8. Southall D: Armed conflict women and girls who are pregnant, infants and children; a neglected public health challenge. What can health professionals do? Early Hum Dev 2011, 87:735-742.

9. Watchlist on Children and Armed Conflict: Caught in the Middle: Mounting Violations Against Children in Nepal's Armed Conflict; 2005. Available at: http://watchlist.org/reports/pdf/nepal.report.20050120.pdf

10. O'Malley B: Education Under Attack. UNESCO; 2007. Available at: http:// unesdoc.unesco.org/images/0018/001863/186303e.pdf

11. Krug EG, Mercy JA, Dahlberg LL, Zwi AB: The world report on violence and health. Lancet 2002, 360:1083-1088.

12. Bustreo F, Genovese E, Omobono E, Axelsson H, Bannon I: Improving Child Health in Post-Conflict Countries Can the World Bank Contribute? Washington, DC: The World Bank; 2005.

13. Collier P: On the economic consequences of civil war. Oxford Econ Pap 1999, 51:168-183.

14. Chen S, Loayza NV, Reynal-Querol M: The aftermath of civil war. Post-Conflict Transitions Working Paper Number 4. Washington, DC: World Bank; 2007.

15. Wells JC: Maternal capital and the metabolic ghetto: an evolutionary perspective on the transgenerational basis of health inequalities. Am J Hum Biol 2010, 22:1-17.

16. Youngson NA, Whitelaw E: Transgenerational epigenetic effects. Annu Rev Genomics Hum Genet 2008, 9:233-257

17. Hackett JA, Sengupta R, Zylicz JJ, Murakami K, Lee C, Down TA, Surani MA: Germline DNA demethylation dynamics and imprint erasure through 5-hydroxymethylcytosine. Science 2013, 339:448-452.

18. Barker DJ, Osmond C: Infant mortality, childhood nutrition, and ischaemic heart disease in England and Wales. Lancet 1986, 327:1077-1081.

19. Barker DJ, Osmond C, Winter PD, Margetts B, Simmonds SJ: Weight in infancy and death from ischaemic heart disease. Lancet 1989, 334:577-580.

20. Watts C, Zimmerman C: Violence against women: global scope and magnitude. Lancet 2002, 359:1232-1237.

21. Swiss S, Jennings PJ, Aryee GV, Brown GH, Jappah-Samukai RM, Kamara MS, Schaack RDH, Turay-Kanneh RS: Violence against women during the Liberian civil conflict. JAMA 1998, 279:625-629.

22. Usta J, Farver JA, Zein L: Women, war, and violence: surviving the experience. J Womens Health (LarChmt) 2008, 17:793-804

23. Rieder M, Choonara I: Armed conflict and child health. Arch Dis Child 2012, 97:59-62.

24. International Action Network on Small Arms: Gun Violence: The Global Crisis, 2008. Available at: http://www.iansa.org/system/files/GlobalCrisis07.pdf

25. Albuja S, Anwar A, Birkeland NM, Caterina M, Charron G, Dolores R, Fajans-Turner A, Ginnetti J, Glatz A, Grayson C, Halff K, Jennings E, Jimenez C, Khalil K, Kok F, Leikvang C, Mancini Beck K, McCallin B, Montemurro M, Perez L, Pierre N, Rothing J, Rushing EJ, Shahinian J, Sheekh NM, Schrepfer N, Spence A, Spurrell C, Tengnäs K, Walick N, et al: In Global Overview 2011. People Internally Displaced by Conflict and Violence. Edited by Birkeland NM, Jennings E, Rushing EJ. Geneva: Norwegian Refugee Council Internal Displacement Monitoring Centre; 2012. Available at: http://www.internal-displacement.org/assets/publications/ 2012/2012-global-overview-2011-global-en.pdf.

26. Machel G: The impact of war on children. UK: C. Hurst \& Co; 2001.

27. Bilukha OO, Brennan M, Anderson M: The lasting legacy of war: epidemiology of injuries from landmines and unexploded ordnance in Afghanistan, 2002-2006. Prehosp Disaster Med 2008, 23:493-499.

28. Cardozo BL, Blanton C, Zalewski T, Tor S, McDonald L, Lavelle J, Brooks R, Anderson M, Mollica R: Mental health survey among landmine survivors in Siem Reap province, Cambodia. Med Confl Surviv 2012, 28:161-181.

29. Lindsey-Curtet C, Holst-Roness FT, Anderson L: Addressing the Needs of Women Affected by Armed Conflict. Geneva: International Committee of the
Red Cross (ICRC; 2004. Available at: http://www.icrc.org/eng/assets/files/ other/icrc_002_0840_women_guidance.pdf.

30. Wood EJ: Variation in sexual violence during war. Polit Soc 2006 34:307-342

31. Marsh M, Purdin S, Navani S: Addressing sexual violence in humanitarian emergencies. Glob Public. Health 2006, 1:133-146.

32. Hynes M, Robertson K, Ward J, Crouse C: A determination of the prevalence of gender-based violence among conflict-affected populations in East Timor. Disasters 2004, 28:294-321.

33. Women's Wellness Center and the Reproductive Health Response in Crises Consortium: RHRC, Prevalence of Gender-Based Violence: Preliminary Findings from a Field Assessment in Nine Villages in the Peja Region, Kosovo; 2006.

34. Martin SL, English KT, Clark KA, Cilenti D, Kupper LL: Violence and substance use among North Carolina pregnant women. Am J Pub Health 1996, 86:991-998.

35. Flynn HA, Walton MA, Chermack ST, Cunningham RM, Marcus SM: Brief detection and co-occurrence of violence, depression and alcohol risk in prenatal care settings. Arch Womens Ment Health 2007, 10:155-161.

36. O'Connor MJ, Tomlinson M, LeRoux IM, Stewart J, Greco E, Rotheram-Borus MJ: Predictors of alcohol use prior to pregnancy recognition among township women in Cape Town, South Africa. Soc Sci Med 2011, 72:83-90.

37. World Health Organization: Interpersonal Violence and Alcohol. http://www. who.int/violence injury_prevention/violence/world report/factsheets/ pb_violencealcohol.pdf.

38. Kilpatrick DG, Acierno R, Resnick HS, Saunders BE, Best CL: A 2-year longitudinal analysis of the relationships between violent assault and substance use in women. J Consult Clin Psychol 1997, 65:834-847.

39. Eaton L, Kalichman S, Sikkema K, Skinner D, Watt M, Pieterse D, Pitpitan E: Pregnancy, alcohol intake, and intimate partner violence among men and women attending drinking establishments in a Cape Town, South Africa Township. J Commun Health 2011, 37:208-216.

40. Jejeebhoy SJ: Associations between wife-beating and fetal and infant death: impressions from a survey in rural India. Stud Fam Plann 1998, 29:300-308.

41. Campbell JC: Health consequences of intimate partner violence. Lancet 2002, 359:1331-1336.

42. Simic S, Idrizbegovic S, Jaganjac N, Boloban H, Puvacic J, Gallic A, Dekovic S: Nutritional effects of the siege on new-born babies in Sarajevo. Eur J Clin Nutr 1995, 49:S33-S36.

43. Gazmararian JA, Petersen R, Spitz AM, Goodwin MM, Saltzman LE, Marks JS: Violence and reproductive health: current knowledge and future research directions. Matern Child Health J 2000, 4:79-84.

44. Kuvacic I, Skrablin S, Hodzic D, Milkovic G: Possible influence of expatriation on perinatal outcome. Acta Obstet Gynecol Scand 1996, 75:367-371.

45. Murphy CC, Schei B, Myhr TL, Du Mont J: Abuse: a risk factor for low birth weight? A systematic review and meta-analysis. CMAJ 2001, 164:1567-1572

46. Maman S, Campbell J, Sweat MD, Gielen AC: The intersections of HIV and violence: directions for future research and interventions. Soc Sci Med 2000, 50:459-478.

47. Heise L, Ellsberg M, Gottemoeller M: Ending violence against women. In Population Reports, Series L, No. 11. Baltimore: Johns Hopkins University, School of Public Health, Population Information Program; 1999:13-18.

48. Nowrojee B: Shattered Lives: Sexual Violence during the Rwandan Genocide and its Aftermath. New York: Human Rights Watch; 1996.

49. Kelly JT, Betancourt TS, Mukwege D, Lipton R, Vanrooyen MJ: Experiences of female survivors of sexual violence in eastern Democratic Republic of the Congo: a mixed-methods study. Confl Health 2011, 5:25.

50. Nelson BD, Collins L, VanRooyen MJ, Joyce N, Mukwege D, Bartels S: Impact of sexual violence on children in the Eastern Democratic Republic of Congo. Med Confl Surviv 2011, 27:211-225.

51. Mollica RF, Mclnnes K, Poole C, Tor S: Dose-effect relationships of trauma to symptoms of depression and post-traumatic stress disorder among Cambodian survivors of mass violence. Br J Psychiatry 1998, 173:482-488.

52. Glaser D: Child abuse and neglect and the brain-a review. J Child Psychol Psychiatry 2000, 41:97-116.

53. Villamor E, Chavarro JE, Caro LE: Growing up under generalized violence: an ecological study of homicide rates and secular trends in age at menarche in Colombia, 1940s-1980s. Econ Hum Biol 2009, $7: 238-245$. 
54. Machel G: Impact of Armed Conflict on Children. UNICEF; 1996. Available at: http://www.unicef.org/graca/a51-306_en.pdf.

55. Morrison AR, Orlando MB, Biehl ML: Social and economic costs of domestic violence: Chile and Nicaragua. In Too Close to Home: Domestic Violence in the Americas. Edited by Morrison ARaB ML. Washington, D.C: Inter-American Development Bank; 1997:51-80.

56. Sharma M, Prasain D, Hutt M: Gender dimensions of the people's war: some reflections on the experiences of rural women. In Himalayan People's War: Nepal's Maoist rebellion. London: Hurst \& Co; 2004:152-165

57. Cahill L, Sherman P: Child abuse and domestic violence. Pediatr Rev 2006, 27:339-345.

58. Boothby N, Crawford J, Halperin J: Mozambique child soldier life outcome study: lessons learned in rehabilitation and reintegration efforts. Glob Public Health 2006, 1:87-107.

59. Otake M, Schull WJ: Radiation-related small head sizes among prenatally exposed A-bomb survivors. Int J Radiat Biol 1993, 63:255-270.

60. Otake M, Schull WJ: Radiation-related brain damage and growth retardation among the prenatally exposed atomic bomb survivors. Int $J$ Radiat Biol 1998, 74:159-171.

61. Abolghasemi H, Radfar MH, Rambod M, Salehi P, Ghofrani H, Soroush MR, Falahaty F, Tavakolifar Y, Sadaghianifar A, Khademolhosseini SM, Kavehmanesh Z, Joffres M, Burkle FM Jr, Mills EJ: Childhood physical abnormalities following paternal exposure to sulfur mustard gas in Iran: a case-control study. Confl Health 2010, 4:13.

62. Alaani S, Tafash M, Busby C, Hamdan M, Blaurock-Busch E: Uranium and other contaminants in hair from the parents of children with congenital anomalies in Fallujah, Iraq. Confl Health 2011, 5:15.

63. Murthy RS, Lakshminarayana R: Mental health consequences of war: a brief review of research findings. World Psychiatry 2006, 5:25-30.

64. Somasundaram D: Child soldiers: understanding the context. BMJ 2002, 324:1268-1271.

65. Derluyn I, Broekaert E, Schuyten G, De Temmerman E: Post-traumatic stress in former Ugandan child soldiers. Lancet 2004, 363:861-863.

66. Betancourt TS, Borisova II, Williams TP, Brennan RT, Whitfield TH, de la Soudiere M, Williamson J, Gilman SE: Sierra Leone's former child soldiers: a follow-up study of psychosocial adjustment and community reintegration. Child Dev 2010, 81:1077-1095.

67. Moscardino U, Scrimin S, Cadei F, Altoe G: Mental health among former child soldiers and never-abducted children in northern Uganda. Scientific World Journal 2012, 2012:367545.

68. Levy BS, Sidel WW: Health effects of combat: a life-course perspective. Annu Rev Public Health 2009, 30:123-136.

69. Thapa SB, Hauff E: Psychological distress among displaced persons during an armed conflict in Nepal. Soc Psychiatry Psychiatr Epidemiol 2005, 40:672-679

70. de Jong JT, Komproe $\mathrm{H}$, Van Ommeren M: Common mental disorders in postconflict settings. Lancet 2003, 361:2128-2130.

71. Seino K, Takano T, Mashal T, Hemat S, Nakamura K: Prevalence of and factors influencing posttraumatic stress disorder among mothers of children under five in Kabul, Afghanistan, after decades of armed conflicts. Health Qual Life Out 2008, 6:29.

72. Klaric M, Klaric B, Stevanovic A, Grkovic J, Jonovska S: Psychological consequences of war trauma and postwar social stressors in women in Bosnia and Herzegovina. Croat Med J 2007, 48:167-176.

73. de Jong JT, Komproe IH, Van Ommeren M, El Masri M, Araya M, Khaled N, van de Put W, Somasundaram D: Lifetime events and posttraumatic stress disorder in 4 postconflict settings. JAMA 2001, 286:555-562.

74. Dimitry $L$ : A systematic review on the mental health of children and adolescents in areas of armed conflict in the Middle East. Child Care Health Dev 2012, 38:153-161.

75. Ezard N, Oppenheimer E, Burton A, Schilperoord M, Macdonald D, Adelekan M, Sakarati $A$, van Ommeren M: Six rapid assessments of alcohol and other substance use in populations displaced by conflict. Confl Health 2011, 5:1.

76. Bhui K, Warfa N: Drug consumption in conflict zones in Somalia. PLoS Med 2007, 4:e354.

77. Kan PR: Drugs and Contemporary Warfare. Herndon, VA: Potomac Books; 2009.

78. Martz E (Ed): Trauma and Rehabilitation after War and Conflict. Springer; 2010.
79. Strathdee SA, Zafar T, Brahmbhatt H, UI Hassan S: Higher level of needle sharing among injection drug users in Lahore, Pakistan, in the aftermath of the US-Afghan war. In International Conference on AIDS. Barcelona; 2002.

80. Hankins CA, Friedman SR, Zafar T, Strathdee SA: Transmission and prevention of HIV and sexually transmitted infections in war settings: implications for current and future armed conflicts. AIDS 2002, 16:2245-2252.

81. Bjelosevic E, Hadzikapetanovic H, Loga S, Hodzic M, Skelic D, Savarimooto B: Relation between benzodiazepine abuse and trauma. Med Arh 2003, 57:33-36.

82. Odenwald M, Neuner F, Schauer M, Elbert T, Catani C, Lingenfelder B, Hinkel H, Hafner $\mathrm{H}$, Rockstroh B: Khat use as risk factor for psychotic disorders: a cross-sectional and case-control study in Somalia. BMC Med 2005, 3:5.

83. Federenko IS, Wadhwa PD: Women's mental health during pregnancy influences fetal and infant developmental and health outcomes. CNS Spectr 2004, 9:198-206

84. Satyanarayana VA, Lukose A, Srinivasan K: Maternal mental health in pregnancy and child behavior. Indian J Psychiatry 2011, 53:351-361.

85. Wachs TD, Black MM, Engle PL: Maternal depression: a global threat to children's health, development, and behavior and to human rights. Child Dev Perspect 2009, 3:51-59.

86. Tegethoff M, Greene N, Olsen J, Schaffner E, Meinlschmidt G: Stress during pregnancy and offspring pediatric disease: a National Cohort Study. Environ Health Perspect 2011, 119:1647-1652.

87. Pesonen AK, Raikkonen K, Kajantie E, Heinonen K, Osmond C, Barker DJ, Forsen T, Eriksson JG: Inter-generational social mobility following early life stress. Ann Med 2011, 43:320-328.

88. Feldman $\mathrm{R}$, Vengrober A: Posttraumatic stress disorder in infants and young children exposed to war-related trauma. J Am Acad Child Adolesc Psychiatr 2011, 50:645-658.

89. Siegmund A, Dahlhoff M, Habersetzer U, Mederer A, Wolf E, Holsboer F, Wotjak $C T$ : Maternal inexperience as a risk factor of innate fear and PTSD-like symptoms in mice. J Psychiatr Res 2009, 43:1156-1165.

90. Seckl JR, Meaney MJ: Glucocorticoid "Programming" and PTSD Risk. Ann N Y Acad Sci 2006, 1071:351-378.

91. Radtke KM, Ruf M, Gunter HM, Dohrmann K, Schauer M, Meyer A, Elbert T: Transgenerational impact of intimate partner violence on methylation in the promoter of the glucocorticoid receptor. Trans/ Psychiatry 2011, 1:e21.

92. Dekel $\mathrm{R}$, Goldblatt $\mathrm{H}$ : Is there intergenerational transmission of trauma? The case of combat veterans' children. Am J Orthopsychiatry 2008, 78:281-289.

93. Betancourt TS, Khan KT: The mental health of children affected by armed conflict: protective processes and pathways to resilience. Int Rev Psychiatry 2008, 20:317-328

94. Chu AT, Lieberman AF: Clinical implications of traumatic stress from birth to age five. Annu Rev Clin Psychol 2010, 6:469-494.

95. Australian Institute of Health and Welfare: Morbidity of Vietnam Veterans. Suicide in Vietnam Veterans' Children, Supplementary Report 1. 1st edition. Canberra: Australian Institute of Health and Welfare; 2000.

96. Kellerman NP: Psychopathology in children of Holocaust survivors: a review of the research literature. Isr J Psychiatry Relat Sci 2001, 38:36-46

97. Yehuda R, Bell A, Bierer LM, Schmeidler J: Maternal, not paternal, PTSD is related to increased risk for PTSD in offspring of Holocaust survivors. J Psychiatr Res 2008, 42:1104-1111.

98. Scharf M, Mayseless O: Disorganizing experiences in second- and thirdgeneration holocaust survivors. Qual Health Res 2011, 21:1539-1553.

99. Gangi S, Talamo A, Ferracuti S: The long-term effects of extreme war-related trauma on the second generation of Holocaust survivors. Violence Vict 2009, 24:687-700.

100. Summerfield D: The psychological legacy of war and atrocity: the question of long-term and transgenerational effects and the need for a broad view. J Nerv Ment Dis 1996, 184:375-377.

101. Scharf M: Long-term effects of trauma: psychosocial functioning of the second and third generation of Holocaust survivors. Dev Psychopathol 2007, 19:603-622.

102. Patel V, Rahman A, Jacob KS, Hughes M: Effect of maternal mental health on infant growth in low income countries: new evidence from South Asia. BMJ 2004, 328:820-823.

103. Galler JR, Harrison RH, Biggs MA, Ramsey F, Forde V: Maternal moods predict breastfeeding in Barbados. J Dev Behav Pediatr 1999, 20:80-87. 
104. Falceto OG, Giugliani ER, Fernandes CL: Influence of parental mental health on early termination of breast-feeding: a case-control study. J Am Board Fam Pract 2004, 17:173-183.

105. Murray L, Cooper P: Effects of postnatal depression on infant development. Arch Dis Child 1997, 77:99-101.

106. Patel V, DeSouza N, Rodrigues M: Postnatal depression and infant growth and development in low income countries: a cohort study from Goa, India. Arch Dis Child 2003, 88:34-37.

107. Galler JR, Harrison RH, Ramsey F, Forde V, Butler SC: Maternal depressive symptoms affect infant cognitive development in Barbados. J Child Psychol Psychiatry 2000, 41:747-757.

108. Galler JR, Ramsey FC, Harrison RH, Taylor J, Cumberbatch G, Forde V: Postpartum maternal moods and infant size predict performance on a national high school entrance examination. J Child Psychol Psychiatry 2004, 45:1064-1075.

109. Osborn DA, Jeffery HE, Cole MJ: Opiate treatment for opiate withdrawal in newborn infants. Cochrane Database Syst Rev 2010, (10), CD002059.

110. Shankaran S, Lester BM, Das A, Bauer CR, Bada HS, Lagasse L, Higgins R: Impact of maternal substance use during pregnancy on childhood outcome. Semin Fetal Neonatal Med 2007, 12:143-150.

111. Mwenda JM, Arimi MM, Kyama MC, Langat DK: Effects of khat (Catha edulis) consumption on reproductive functions: a review. East Afr Med J 2003, 80:318-323.

112. Strand RT, Fernandes Dias L, Bergstrom S, Andersson S: Unexpected low prevalence of HIV among fertile women in Luanda, Angola. Does war prevent the spread of HIV? Int J STD AIDS 2007, 18:467-471.

113. Guerin PJ, Brasher C, Baron E, Mic D, Grimont F, Ryan M, Aavitsland P, Legros D: Shigella dysenteriae serotype 1 in west Africa: intervention strategy for an outbreak in Sierra Leone. Lancet 2003, 362:705-706

114. Griffith DC, Kelly-Hope LA, Miller MA: Review of reported cholera outbreaks worldwide, 1995-2005. Am J Trop Med Hyg 2006, 75:973-977.

115. Gayer M, Legros D, Formenty P, Connolly MA: Conflict and emerging infectious diseases. Emer Infect Dis 2007, 13:1625-1631.

116. United Nations High Commissioner for Refugees. [http://www.unhcr.org/]

117. Shears P, Berry AM, Murphy R, Nabil MA: Epidemiological assessment of the health and nutrition of Ethiopian refugees in emergency camps in Sudan, 1985. Med J (Clin Res Ed) 1987, 295:314-318.

118. Brewer IW: The control of communicable diseases in camps. Am J Pub Health 1918, 8:121-124.

119. Connolly MA, Heymann DL: Deadly comrades: war and infectious diseases. Lancet 2002, 360:s23-s24

120. Fair J, Jentes E, Inapogui A, Kourouma K, Goba A, Bah A, Tounkara M, Coulibaly M, Garry RF, Bausch DG: Lassa virus-infected rodents in refugee camps in Guinea: a looming threat to public health in a politically unstable region. Vector Borne Zoonotic Dis 2007, 7:167-171.

121. Bonner PC, Schmidt WP, Belmain SR, Oshin B, Baglole D, Borchert M: Poor housing quality increases risk of rodent infestation and Lassa fever in refugee camps of Sierra Leone. Am J Trop Med Hyg 2007, 77:169-175.

122. Rowland M, Rab MA, Freeman T, Durrani N, Rehman N: Afghan refugees and the temporal and spatial distribution of malaria in Pakistan. Soc Sci Med 2002, 55:2061-2072

123. Singh S, Bohler E, Dahal K, Mills E: The state of child health and human rights in Nepal. PLoS Med 2006, 3:e203.

124. Health care in danger. http://www.icrc.org/eng/what-we-do/safeguardinghealth-care/index.jsp.

125. Mann J, Drucker E, Tarantola D: Bosnia: the war against public health. Med Global Survival 1994, 1:130-144.

126. Nathanson V: Delivering healthcare in situations of conflict or violence. BMJ 2011, 343:d4671.

127. ICRC: Iraq: Civilians without Protection: the Ever-Worsening Humanitarian Crisis; 2007. Available at: http://www.icrc.org/eng/assets/files/other/iraq-report-icrc. pdf.

128. Msuya C, Sondorp E: Interagency Health Evaluation Liberia; 2005. Available at: http://www.alnap.org/resource/3392.aspx.

129. De Schryver A, Meheus A: Epidemiology of sexually transmitted diseases: the global picture. Bull World Health Organ 1990, 68:639-654.

130. Ward J, Vann B: Gender-based violence in refugee settings. Lancet 2002, 360:s13-s14.
131. Kinyanda $E$, Weiss $H A$, Mungherera $M$, Onyango-Mangen $P$, Ngabirano $E$, Kajungu R, Kagugube J, Muhwezi W, Muron J, Patel V: Psychiatric disorders and psychosocial correlates of high HIV risk sexual behaviour in war-affected Eastern Uganda. AIDS Care 2012, 24:1323-1332

132. Cossa HA, Gloyd S, Vaz RG, Folgosa E, Simbine E, Diniz M, Kreiss JK: Syphilis and HIV infection among displaced pregnant women in rural Mozambique. Int J STD AIDS 1994, 5:117-123.

133. Civilians in war zones; women and children worst. Economist 2009. Available at: http://www.economist.com/node/13145799.

134. Oxford JS, Sefton A, Jackson R, Innes W, Daniels RS, Johnson NP: World War I may have allowed the emergence of "Spanish" influenza. Lancet Infect Dis 2002, 2:111-114.

135. Erkoreka A: Origins of the Spanish Influenza pandemic (1918-1920) and its relation to the First World War. J Mol Genet Med 2009, 3:190-194.

136. Mazumder B, Almond D, Park K, Crimmins EM, Finch CE: Lingering prenatal effects of the 1918 influenza pandemic on cardiovascular disease. J Dev Orig Health Dis 2010, 1:26-34.

137. Almond D: Is the 1918 influenza pandemic over? Long-term effects of in utero influenza exposure in the post-1940 U.S. population. J Polit Econ 2006 1918, 114:672-712.

138. Novo A, Huebschen JM, Muller CP, Tesanovic M, Bojanic J: Ongoing rubella outbreak in Bosnia and Herzegovina, March-July 2009-preliminary report. Euro Surveill 2009, 14. pii: 19343.

139. Saigal S, Doyle LW: An overview of mortality and sequelae of preterm birth from infancy to adulthood. Lancet 2008, 371:261-269.

140. Le Doare K, Bland R, Newell ML: Neurodevelopment in children born to HIV-infected mothers by infection and treatment status. Pediatrics 2012, 130:e1326-e1344.

141. Fernando D, Wickremasinghe R, Mendis KN, Wickremasinghe AR: Cognitive performance at school entry of children living in malaria-endemic areas of Sri Lanka. Trans R Soc Trop Med Hyg 2003, 97:161-165.

142. Clarke SE, Jukes MC, Njagi JK, Khasakhala L, Cundill B, Otido J, Crudder C, Estambale BB, Brooker S: Effect of intermittent preventive treatment of malaria on health and education in schoolchildren: a cluster-randomised, double-blind, placebo-controlled trial. Lancet 2008, 372:127-138.

143. Kihara M, Carter JA, Newton CR: The effect of Plasmodium falciparum on cognition: a systematic review. Trop Med Int Health 2006, 11:386-397.

144. Simetka O, Reilley B, Joseph M, Collie M, Leidinger J: Obstetrics during civil war: six months on a maternity ward in Mallavi, northern Sri Lanka. Med Confl Surviv 2002, 18:258-270.

145. Childbirth at checkpoints in the occupied Palestinian territory. Abstract available at: http://download.thelancet.com/flatcontentassets/pdfs/palestine/ palestine2011-4.pdf.

146. Hudic I, Radoncic F, Fatusic Z: Incidence and causes of maternal death during 20-year period (1986-2005) in Tuzla Canton, Bosnia and Herzegovina. J Matern Fetal Neonatal Med 2011, 24:1286-1288.

147. Strong MA: The health of adults in the developing world: the view from Bangladesh. Health Transit Rev 1992, 2:215-224.

148. Anderson FW, Morton SU, Naik S, Gebrian B: Maternal mortality and the consequences on infant and child survival in rural Haiti. Matern Child Health J 2007, 11:395-401.

149. Complex Emergency Database. [http://www.cedat.be/]

150. World Health Organization: Public Health Risk Assessment and Interventions. The Horn of Africa: Drought and Famine Crisis. Geneva; 2011.

151. Egal F: Nutrition in conflict situations. Br J Nutr 2006, 96:S17-19.

152. Hendrie B: Relief aid behind the lines: the cross-border operation in Tigray. In War and Hunger Rethinking International Responses to Complex Emergencies. Edited by Macrae J, Zwi A, Duffield M, Slim M. London: Zed Books; 1994:125-139.

153. Baten J, Wagner A: Autarchy, market disintegration, and health: the mortality and nutritional crisis in Nazi Germany, 1933-1937. Econ Hum Biol 2002, 1:1-28.

154. Ali MM, Shah $\mathrm{H}$ : Sanctions and childhood mortality in Iraq. Lancet 2000, 355:1851-1857.

155. Zakanj Z, Armano G, Grguric J, Herceg-Cavrak V: Influence of 1991-1995 war on breast-feeding in Croatia: questionnaire study. Croat Med J 2000 41:186-190.

156. Jakobsen M, Sodemann M, Nylen G, Bale C, Nielsen J, Lisse I, Aaby P. Breastfeeding status as a predictor of mortality among refugee children in an emergency situation in Guinea-Bissau. Trop Med Int Health 2003, 8:992-996. 
157. Andersson N, Paredes-Solis S, Legorreta-Soberanis J, Cockcroft A, Sherr L: Breast-feeding in a complex emergency: four linked cross-sectional studies during the Bosnian conflict. Public Health Rep 2010, 13:2097-2104.

158. Victora CG, Adair L, Fall C, Hallal PC, Martorell R, Richter L, Sachdev HS: Maternal and child undernutrition: consequences for adult health and human capital. Lancet 2008, 371:340-357.

159. Cheung E, Mutahar R, Assefa F, Ververs MT, Nasiri SM, Borrel A, Salama P: An epidemic of scurvy in Afghanistan: assessment and response. Food Nutr Bull 2003, 24:247-255.

160. Seal AJ, Creeke PI, Dibari F, Cheung E, Kyroussis E, Semedo P, van den Briel T: Low and deficient niacin status and pellagra are endemic in postwar Angola. Am J Clin Nutr 2007, 85:218-224.

161. Lumey LH: Decreased birthweights in infants after maternal in utero exposure to the Dutch famine of 1944-1945. Paediatr Perinat Epidemio 1992, 6:240-253.

162. Brialic I, Rodin U, Vrdoljak J, Plavec D, Capkun V: Secular birth weight changes in liveborn infants before, during, and after 1991-1995 homeland war in Croatia. Croat Med J 2006, 47:452-458.

163. Hogue CJ, Buehler JW, Strauss LT, Smith JC: Overview of the national infant mortality surveillance (NIMS) project-design, methods, results. Public Health Rep 1987, 102:126-138.

164. Pena-Rosas JP, Viteri FE: Effects and safety of preventive oral iron or iron +folic acid supplementation for women during pregnancy. Cochrane Database Syst Rev 2009, 4, CD004736.

165. De-Regil LM, Fernandez-Gaxiola AC, Dowswell T, Pena-Rosas JP: Effects and safety of periconceptional folate supplementation for preventing birth defects. Cochrane Database Syst Rev 2010, 10, CD007950.

166. Wells JC, Chomtho S, Fewtrell MS: Programming of body composition by early growth and nutrition. Proc Nutr Soc 2007, 66:423-434.

167. Gudmundsson S, Henningsson AC, Lindqvist P: Correlation of birth injury with maternal height and birthweight. BJOG 2005, 112:764-767.

168. Moses RG, Mackay MT: Gestational diabetes: is there a relationship between leg length and glucose tolerance? Diab Care 2004, 27:1033-1035.

169. Myklestad K, Vatten L, Magnussen EB, Salvesen KA, Romundstad PR: Do parental heights influence pregnancy length? A population-based prospective study, HUNT 2. BMC Pregnancy Childbirth 2013, 13:33.

170. Clarkin PF: Adiposity and height of adult Hmong refugees: relationship with war-related early malnutrition and later migration. Am J Hum Biol 2008, 20:174-184.

171. Fishman SM, Caulfield L, de Onis M: Childhood and maternal underweight In Comparative Quantification of Health Risks: Global and Regional Burden of Disease Attributable to Selected Major Risk Factors. Edited by Ezzati M, Lopez AD, Rodgers A, Murray CLJ. Geneva: World Health Organization; 2004:39-161.

172. Maternal anthropometry and pregnancy outcomes. A WHO collaborative study. Bull World Health Organ 1995, 73:1-98.

173. Horta BL, Gigante DP, Osmond C, Barros FC, Victora CG: Intergenerational effect of weight gain in childhood on offspring birthweight. Int J Epidemiol 2009, 38:724-732.

174. Greenfeld C, Flaws JA: Renewed debate over postnatal oogenesis in the mammalian ovary. BioEssays 2004, 26:829-832

175. Bukovsky A, Caudle MR, Svetlikova M, Wimalasena J, Ayala ME, Dominguez R: Oogenesis in adult mammals, including humans: a review. Endocrine 2005, 26:301-316.

176. Ravelli G-P, Stein ZA, Susser MW: Obesity in young men after famine exposure in utero and early infancy. N Engl J Med 1976, 295:349-353.

177. Roseboom TJ, van der Meulen JH, Ravelli AC, Osmond C, Barker DJ, Bleker OP: Effects of prenatal exposure to the Dutch famine on adult disease in later life: an overview. Mol Cell Endocrinol 2001, 185:93-98.

178. Stein AD, Zybert PA, van der Pal-de Bruin K, Lumey LH: Exposure to famine during gestation, size at birth, and blood pressure at age $59 \mathrm{Y}$ : evidence from the Dutch famine. Eur J Epidemiol 2006, 21:759-765.

179. Ravelli AC, van Der Meulen JH, Osmond C, Barker DJ, Bleker OP: Obesity at the age of $50 \mathrm{y}$ in men and women exposed to famine prenatally. Am J Clin Nutr 1999, 70:811-816.

180. Stein AD, Kahn HS, Rundle A, Zybert PA, van der Pal-de Bruin K, Lumey LH: Anthropometric measures in middle age after exposure to famine during gestation: evidence from the Dutch famine. Am J Clin Nutr 2007, 85:869-876
181. Stein $A D$, Lumey $L H$ : The relationship between maternal and offspring birth weights after maternal prenatal famine exposure: the Dutch famine birth cohort study. Hum Biol 2000, 72:641-654

182. Hult M, Tornhammar P, Ueda P, Chima C, Edstedt Bonamy AK, Ozumba B, Norman M: Hypertension, diabetes and overweight: looming legacies of the Biafran famine. Plos One 2010, 5:e13582.

183. Zheng X, Wang Y, Ren W, Luo R, Zhang S, Zhang JH, Zeng Q: Risk of metabolic syndrome in adults exposed to the great Chinese famine during the fetal life and early childhood. Eur J Clin Nutr 2012, 66:231-236.

184. Yang Z, Zhao W, Zhang X, Mu R, Zhai Y, Kong L, Chen C: Impact of famine during pregnancy and infancy on health in adulthood. Obes Rev 2008, 9:95-99.

185. Li Y, Jaddoe WW, Qi L, He Y, Wang D, Lai J, Zhang J, Fu P, Yang X, Hu FB: Exposure to the Chinese famine in early life and the risk of metabolic syndrome in adulthood. Diab Care 2011, 34:1014-1018.

186. Huang C, Li Z, Wang M, Martorell R: Early life exposure to the 1959-1961 Chinese famine has long-term health consequences. J Nutr 2010, 140:1874-1878.

187. St Clair D, Xu M, Wang P, Yu Y, Fang Y, Zhang F, Zheng X, Gu N, Feng G, Sham $P$, He L: Rates of adult schizophrenia following prenatal exposure to the Chinese famine of 1959-1961. JAMA 2005, 294:557-562.

188. Xu MQ, Sun WS, Liu BX, Feng GY, Yu L, Yang L, He G, Sham P, Susser E, St Clair D, He L: Prenatal malnutrition and adult schizophrenia: further evidence from the 1959-1961 Chinese famine. Schizophr Bull 2009, 35:568-576.

189. Westing AH: Warfare in a fragile world: military impacts on the human environment. London: Taylor and Francis; 1980.

190. World Health Organization: Dioxins and their effects on human health. Fact Sheet No 225, May 2010. Available at: http://www.who.int/mediacentre/ factsheets/fs225/en/.

191. Martin M: Vietnamese victims of Agent Orange and US-Vietnam relations. Congressional Research Service 7-5700 CRS Report for Congress May 28 2009 (re level of Agent Orange used); 2009.

192. United Nations Convention on the Rights of the Child. Available at: [http:// www.unicef.org/crc]

193. Osmani S, Sen A: The hidden penalties of gender inequality: fetal origins of ill-health. Econ Hum Biol 2003, 1:105-121.

194. Holsboer F: The corticosteroid receptor hypothesis of depression. Neuropsychopharmacol 2000, 23:477-501.

195. Schmidt U, Holsboer F, Rein T: Epigenetic aspects of posttraumatic stress disorder. Dis Markers 2011, 30:77-87.

196. Francis D, Diorio J, Liu D, Meaney MJ: Nongenomic transmission across generations of maternal behavior and stress responses in the rat. Science 1999, 286:1155-1158.

197. Liu D, Diorio J, Tannenbaum B, Caldji C, Francis D, Freedman A, Sharma S, Pearson D, Plotsky PM, Meaney MJ: Maternal care, hippocampal glucocorticoid receptors, and hypothalamic-pituitary-adrenal responses to stress. Science 1997, 277:1659-1662.

198. Weaver IC, Champagne FA, Brown SE, Dymov S, Sharma S, Meaney MJ, Szyf M: Reversal of maternal programming of stress responses in adult offspring through methyl supplementation: altering epigenetic marking later in life. J Neurosci 2005, 25:11045-11054

199. Weaver IC, Meaney MJ, Szyf M: Maternal care effects on the hippocampal transcriptome and anxiety-mediated behaviors in the offspring that are reversible in adulthood. Proc Natl Acad Sci U S A 2006, 103:3480-3485.

200. Gardner H, Kobtzeff O \{Eds): The Ashgate Research Companion to War: Origins and Prevention. Ashgate: Farnham; 2012.

201. ICRC/IFRC: Guidelines for Assessment in Emergencies. Geneva, Switzerland: ICRC and the IFRCRC; 2008. Available at: http://psychosocial.actalliance.org/ default.aspx?di=66841.

202. The Sphere Project: The Sphere Handbook: Humanitarian Charter and Minimum Standards in Humanitarian Response; 2011.

203. World Health Organization: Integrating Sexual and Reproductive Health into Health Emergency and Disaster Risk Management. Geneva; 2012.

204. Office of the Special Representative of the Secretary-General for Children and Armed Conflict: The Six Grave Violations Against Children During Armed Conflict: The Legal Foundation Working Paper 1. New York; 2009.

10.1186/1741-7015-12-57

Cite this article as: Devakumar et al:: The intergenerational effects of war on the health of children. BMC Medicine 2014, 12:57 